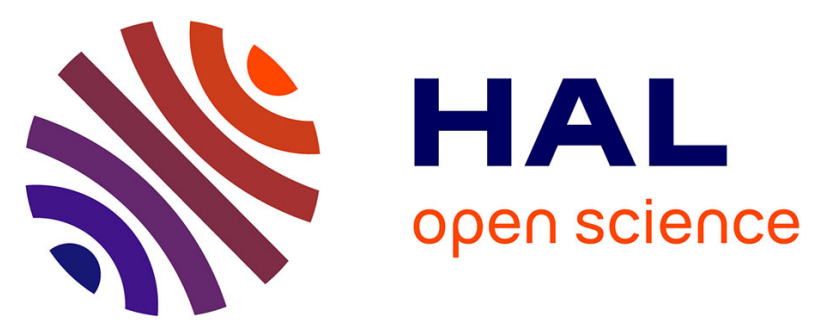

\title{
Chemical extractions and predicted free ion activities fail to estimate metal transfer from soil to field land snails.
}

Brice Mourier, Clémentine Fritsch, Elie Dhivert, Frédéric Gimbert, Michael

Coeurdassier, Benjamin Pauget, Annette De Vaufleury, Renaud Scheifler

\section{- To cite this version:}

Brice Mourier, Clémentine Fritsch, Elie Dhivert, Frédéric Gimbert, Michael Coeurdassier, et al.. Chemical extractions and predicted free ion activities fail to estimate metal transfer from soil to field land snails.. Chemosphere, 2011, 85 (6), pp.1057-65. 10.1016/j.chemosphere.2011.07.035 . hal00682800

\section{HAL Id: hal-00682800 \\ https://hal.science/hal-00682800}

Submitted on 26 Mar 2012

HAL is a multi-disciplinary open access archive for the deposit and dissemination of scientific research documents, whether they are published or not. The documents may come from teaching and research institutions in France or abroad, or from public or private research centers.
L'archive ouverte pluridisciplinaire $\mathbf{H A L}$, est destinée au dépôt et à la diffusion de documents scientifiques de niveau recherche, publiés ou non, émanant des établissements d'enseignement et de recherche français ou étrangers, des laboratoires publics ou privés. 
1 Chemical extractions and predicted free ion activities fail to estimate

3

4 Brice Mourier*, Clémentine Fritsch, Elie Dhivert, Frédéric Gimbert, Michaël Cœurdassier,

5 Annette de Vaufleury, Renaud Scheifler

6

7 Chrono-Environment, UMR 6249 University of Franche-Comté/CNRS UsC INRA, Place

8 Leclerc, F-25030 Besançon Cedex, France

* Corresponding author:

11 Dr Brice MOURIER

12 Mail: brice.mourier@univ-fcomte.fr

13 Address: Chrono-Environment, UMR 6249 University of Franche-Comté/CNRS Usc INRA, 14 Place Leclerc, F-25030 Besançon Cedex, France

15 Phone: +33 (0) 381665763 ,

16 Fax: $+33(0) 381665797$

18 E-mail addresses:

19 Michaël COEURDASSIER: michael.coeurdassier@univ-fcomte.fr

20 Elie DHIVERT: elie.dhivert@orange.fr

21 Clémentine FRITSCH: clementine.fritsch@univ-fcomte.fr

22 Frédéric GIMBERT: frederic.gimbert@univ-fcomte.fr

23 Brice MOURIER: brice.mourier@univ-fcomte.fr

24 Annette de VAUFLEURY: annette.devaufleury@univ-fcomte.fr 


\section{ABSTRACT}

This study investigates the relevance of several soil chemical extractions $\left(\mathrm{CaCl}_{2}\right.$, acetic acid, citric acid and a four-step sequential procedure) and of predicted free metal ion activities in the soil solution (according to equations using total concentrations and $\mathrm{pH}$ ) to characterize the transfer of trace metals $(\mathrm{Cd}, \mathrm{Pb}$ and $\mathrm{Zn})$ from soil to snail soft tissues over a large smelter-impacted area (Metaleurop Nord, Nord-Pas-de-Calais, France). The study was firstly performed on 6 wild snail species together and then, specifically, on Cepaea sp and Oxychilus draparnaudi, which were well distributed over the study area and have contrasted diet (Cepaea snails are herbivorous while $O$. draparnaudi is carnivorous). When the 6 species were considered together, the accumulation depended most on the species, total or extractable metal concentrations in soils, or predicted free ion activities, accounting for less than $7 \%$ of the variation of metal concentrations in snail tissues. Species-specific analyses showed that extractable concentrations explained around $25 \%$ of the variation of metal concentrations in O. draparnaudi while it was up to $8 \%$ for Cepaea snails. When using total soil concentrations and soil properties as explanatory variables, models were generally slightly better, especially in species-specific analyses, explaining up to $42 \%$ of the variance. These results show that the soil extraction procedures used in this study, and predicted free ion activities of soil pore water, could not accurately estimate metal transfer from the environment to snails, probably because they do not take into account other sources of exposure than soil, and thus could not be used in risk assessment. Insight has to be gained into the determination on food web structure and composition and subsequent contaminant transfers, in order to improve risk assessment for such organisms. 


\section{Introduction}

Due to historical and modern industrial activities, soils can be severely contaminated with metals (e.g. cadmium, $\mathrm{Cd}$; lead, $\mathrm{Pb}$; and zinc, $\mathrm{Zn}$ ) and the release of such contaminants in natural systems can consequently pose environmental and human health risks. In the case of areas affected by metallurgical industries, the original load is primarily sourced from smelter fallout and dusts from spoil heaps that have been transported across natural systems. Exposure of organisms to trace metals depends on many non-biotic factors (including, for instance, the spatial distribution of metals in soils, landscape or habitat features, season etc) as well as the biological characteristics of the organism itself like its diet and, more generally, its life history traits (Suter II, 1993). In line with that, Landrum et al. (1994) developed the concept of environmental bioavailability as the fraction of the environmental availability (modulated by physicochemically-driven processes) that is available over the exposure period for uptake (physiologically-driven processes) by a given species (Peijnenburg and Jager, 2003).

In the framework of ecotoxicology and ecological risk assessment, terrestrial invertebrates have been extensively studied as biomonitors of environmental contamination by metals. The relationships between concentrations of metals in snails and in soils have been well studied in controlled conditions as well as on the field. Those studies generally have shown that concentrations in snail tissues are related to the contamination of their environment (Berger and Dallinger, 1993). The biota-to-soil concentrations ratios (BSAFs) that can be derived from these studies may be useful in ecological risk assessment (Veltman et al., 2008). However, relationships between total metal concentrations in soil and concentrations in snail soft tissues are usually relatively low, hampering accurately predicting concentrations in organisms from total soil concentrations. For instance, coefficient of determination $\left(R^{2}\right)$ of the relationship between Cepaea nemoralis snail and soil concentrations were of $0.33,0.17$ and 0.15 for $\mathrm{Cd}, \mathrm{Pb}$ and $\mathrm{Zn}$, respectively (Notten et al., 2005). Such low relationships may be due to the fact that total metal concentrations are usually considered not to be the best estimate of bioavailability for both plants and organisms (Harmsen, 2007).

In order to overcome this limitation, a variety of chemical methods has been developed to estimate the available fraction of metals in soils, and then to correlate these available concentrations with metal levels in tissues or with effects observed in organisms. Among these methods, single or sequential extraction techniques have given satisfactory results for certain pollutants, certain soils and/or certain organisms (see, for instance, Harmsen, 2007; Meers et al., 2007; Hass and Fine, 2010), even if it is clear that no universal extractant exists. Free metal ion activity in the soil solution has also been suggested as a pertinent estimate of metal bioavailability and toxicity in aquatic organisms and higher plants (Smolders et al., 2009) and may therefore be hypothesised as a good predictor of metal 
concentrations in soil organisms (Sauvé et al., 2000). Though, studies examining relationships between metal concentrations in soil organisms and free ion activities in pore water or extractable metal concentrations in soil are scarce.

Within this context, we hypothesized that chemically extractable metal concentrations in soils, or predicted free ion activity, would give better relationships with metal concentrations in snail tissues, than total metal concentrations in soils. We thus aimed at comparing the relationships between total or extractable (using three selective extractions and a four-step sequential procedure) soil concentrations or predicted free ion activities and metal concentrations in snail soft tissues. As an alternative to the use of extractable concentrations, we also modelled metal concentrations in snail tissues using total metal concentrations in soils and soil properties.

\section{Materials and methods}

\subsection{Study site and sampling strategy}

This study was carried out in the surroundings of the former "Metaleurop-Nord" smelter in Northern France (Noyelles-Godault, Nord-Pas-de-Calais, 50²5’42 N 300'55 E). This area is considered as highly polluted with $\mathrm{Cd}, \mathrm{Pb}$ and $\mathrm{Zn}$ for both levels of contamination and surfaces of concern (Sterckeman et al., 2002b; Douay et al., 2008; Douay et al., 2009; Fritsch et al., 2010). A $40 \mathrm{~km}^{2}(8 \times 5 \mathrm{~km})$ study area, centred on the former smelter, was defined. This area was split into 160 squares (500 m-sided), which constituted our sampling units. Because of logistical constraints, the present study was performed on 30 squares located along a soil pollution gradient, chosen among the 160. In each of the 30 squares, one to 10 composite soil samples (constituted each by 15 randomly placed sub-samples in a homogeneous patch) were taken in woody patches (woodlots, hedgerows, tree plantations, etc) during autumn 2006. Soil sampling was carried out on the first $25 \mathrm{~cm}$ and the litter layer (OL layer constituted by the accumulation of no- or few decomposed leaves and woody fragments on the soil surface) was removed. However, the humus layer (OF layer constituted of fragmented residues) was sampled with the top mineral soil material, in accordance with the most frequently recommended protocol in Europe. Detailed data about soil sampling, soil physico-chemical characteristics and contamination are given in Douay et al (Douay et al., 2009) and Fritsch et al (Fritsch et al., 2010). Snails were hand-searched during autumn 2006 in patches where soils were sampled. Snails were sampled in the morning, stored in plastic bags without food and frozen at night. This allowed a depuration period of around 8 hours.

\subsection{Determination of snail species and age and preparation of snail tissues}


124 Species were determined according to morphometric criteria (Kerney and Cameron, 2006).

125 Snails belonging to the Cepaea genus were classified according to two classes of relative 126 age (adults or juveniles), according to the presence or the absence, respectively, of a clear 127 white or brown-black lip at the mouth of their shell (Williamson, 1979). The presence of this 128 lip indicates that the snail has attained adulthood. In these Cepaea snails, the determination 129 at a species level is only possible on adults. In the case of non reproductive juveniles, the snails were called "Cepaea juveniles". Class age was not determined for the other snail species due to the absence of published ageing method and/or to insufficient sample size to take age into account in statistical treatments.

The soft body of the snails was separated from the shell and dried in an oven $\left(60^{\circ} \mathrm{C}\right)$ to constant dry weight before metals analysis. Snails were generally analysed individually, but when their dry mass was lower than $0.1 \mathrm{~g}$, two to 10 individuals (depending on the mass of the individuals) were pooled to obtain a sufficient biomass for metals analysis. For both individual and pooled samples, snail metal concentrations were normalized to soft tissues weight.

\subsection{Analyses of metals concentrations in soils and animals}

141 Soils were analyzed for total and extractable metal concentrations and for soil properties.

142 The protocols are detailed in Douay et al. (2009). Briefly, samples were dried, disaggregated

143 and homogenized before sieving to $250 \mu \mathrm{m}$. The following soil characteristics were 144 measured: granulometry, $\mathrm{pH}$ (water suspension), organic carbon content (OC), organic matter $(\mathrm{OM})$, total carbonate content $\left(\mathrm{CaCO}_{3}\right)$ and cation exchange capacity (CEC). Total $\mathrm{Cd}$ and $\mathrm{Pb}$ concentrations were measured by inductively-coupled argon plasma mass spectrophotometry (ICP-MS) and Zn concentrations by inductively-coupled argon plasma atomic emission spectrophotometry (ICP-AES) after a total digestion with a mixture of hydrofluoric (HF) and perchloric $\left(\mathrm{HClO}_{4}\right)$ acids. Soil properties as well as metals concentrations in soils were analyzed by the Laboratoire d'Analyse des Sols of the Institut National de la Recherche Agronomique (INRA), of Arras (France), which is accredited by the French Accreditation Committee (COFRAC, $\mathrm{n}^{\circ} 1$ 1380) for the analytical quality for soil characteristics and metals concentration measurements.

Three selective extractions and one sequential four-step extraction were chosen. Calcium chloride $\left(\mathrm{CaCl}_{2}, 0.01 \mathrm{M}\right)$ was chosen to estimate cation exchange reactions and because it is considered as relevant for the assessment of the bioavailable fraction of $\mathrm{Cd}, \mathrm{Pb}$ and $\mathrm{Zn}$ to plants and soil invertebrates (Harmsen, 2007; ISO, 2008). Acetic acid $\left(\mathrm{C}_{2} \mathrm{H}_{4} \mathrm{O}_{2}, 0.11 \mathrm{M}\right)$ and citric acid $\left(\mathrm{C}_{6} \mathrm{H}_{8} \mathrm{O}_{7}, 0.11 \mathrm{M}\right)$ are two low molecular weight organic acids (LMWOA) mostly present in the rhizosphere of many plants and used to simulate complexing behaviour of root exudates (Meers et al., 2007). These two LMWOA increase the overall metal solubility by 
161

162

163

164

165

166

167

168

169

170

171

172

173

174

175

176

177

178

179

180

181

182

183

184

185

186

187

188

189

190

191

192

193

194

195

196

dissolution of hydroxides and carbonates and by acting as complexing agents. Acetic acid extractable fraction has been used as an estimate of the metal bioavailability to soil animals (Morgan and Morgan, 1999; Lukkari et al., 2004). Citric acid has been used to simulate the physicochemical characteristics of root environment of the plant (Ahumada et al., 2004). A three-stage sequential extraction procedure was also performed, allowing the extraction of four operationally defined fractions: acid-soluble extracted by $0.11 \mathrm{M}$ acetic acid (exchangeable and carbonate bound), reducible extracted by $0.5 \mathrm{M}$ of hydroxylammonium chloride at pH 2 (Fe- and Mn-oxide bound), oxidizable extracted by $8.8 \mathrm{M}$ of $\mathrm{H}_{2} \mathrm{O}_{2}$ followed by $1 \mathrm{M}$ of ammonium acetate at $\mathrm{pH} 2$ (organic matter and sulfide bound) and residual extracted by hydrofluoric (48\%) and perchloric (70\%) acids (included within silicate matrix). The extractable concentrations of those four fractions will be called $a, b, d$ and $r$, respectively, later in this article. Extractable metal concentrations were quantified using atomic absorption spectrometry (AAS, AA-6800, Shimadzu) by the Laboratoire Sols et Environnement of the Institut Supérieur d'Agriculture (ISA), Lille, France. Three independent replicates were performed for each sample and blanks were measured in parallel for each set of analyses, measurements of certified reference materials (i.e. BCR-701 and BCR-483) was were used to ensure the quality of the results obtained. For all metals average recoveries of the CRMs were at $X X \% \pm 10 \%$.

Finally, predicted free ion activities in the soil solution $\left(\mathrm{pPb}^{2+}, \mathrm{pCd}^{2+}, \mathrm{pZn}^{2+}\right)$ were calculated from $\mathrm{pH}$ and total metal concentrations using the equations proposed by (Sauvé et al., 1997; Sauvé et al., 2000; Stephan et al., 2008), respectively. As calculated by those equations, the activity of metal ions corresponds to - $\log$ (free ion concentration in $\mathrm{M}$ ).

Metal concentrations in snail soft bodies were measured by furnace $(\mathrm{Cd}, \mathrm{Pb})$ or flame $(\mathrm{Zn})$ atomic absorption spectrometry (VARIAN $220 Z$ and 220FS, respectively) at the ChronoEnvironment Department of the University of Franche-Comté, Besançon, France. Digestion of samples was performed using dissolution in nitric acid $\left(\mathrm{HNO}_{3}, 65 \%\right.$, Carlo-Erba analytical quality) in a dry oven $\left(65^{\circ} \mathrm{C}\right)$ during $72 \mathrm{~h}$. After digestion, samples were diluted adding ultrapure water (18.2 M $\Omega \cdot \mathrm{cm}^{-2}$ ). Blanks (acid + ultra-pure water) and Certified Reference Materials (CRMs, TORT-2 and DOLT-3, National Research Council, Canada) were prepared and analyzed using the same methods.

Average recoveries of the CRMs were at $95 \% \pm 10 \%(n=38)$ for $\mathrm{Cd}, 101 \% \pm 17 \%(n=42)$ for $\mathrm{Pb}, 80 \% \pm 2 \%(n=22)$ for $\mathrm{Zn}$. Detection limits in snail soft bodies were $0.14,0.20$ and 4.4 $\mu \mathrm{g} \cdot \mathrm{g}^{-1}$ for $\mathrm{Cd}, \mathrm{Pb}$ and $\mathrm{Zn}$, respectively. For both soils and animals, metal concentrations were expressed as micrograms per grams dry weight $\left(\mu \mathrm{g} \cdot \mathrm{g}^{-1} \mathrm{dw}\right)$.

\subsection{Statistical analyses}


197 For each sampled individual, the following data were available: snail species, metal concentrations in soft tissues, and age for Cepaea snails. Environmental data available were total and extractable metal concentrations and soil properties (clay, silt, sand, $\mathrm{pH}, \mathrm{CaCO}_{3}$, CEC, OC and OM) in the soil of the patch where the individual was caught. The statistical distribution of the data was checked with the test of Shapiro. Because metal concentrations in soils and animals were skewed, variables were $\log _{10}(x+1)$ transformed for statistical analyses. These transformations allowed matching the assumptions of normality and linearity which are required to perform General Linear Models (GLM).

First, principal component analyses were performed on soil properties to identify redundant variables. According to those analyses, $\mathrm{pH}, \mathrm{OM}, \mathrm{CEC}$, clay and silt were retained for further analyses. Simple linear regressions were also performed to explore relationships between snail and soil concentrations, and between biotic (species or age) and abiotic variables (soil properties or metal concentrations).

Second, relationships between metal concentrations in snail tissues and in soils (total or extractable concentrations, or predicted free ion activities in the soil pore water) were determined. General Linear models (GLM) (Grafen and Hails, 2002) were performed using metal concentration in snail tissues as dependant variable and species and metal concentrations in soils as explanatory variables. Specific analyses were then made for $O$. draparnaudi and Cepaea sp. because of their relative abundance and their homogeneous spatial distribution over the study area. Moreover, these two species have clearly distinct diet, O. draparnaudi being carnivorous while Cepaea snails are herbivorous (Kerney and Cameron, 2006). Concentrations of metals in O. draparnaudi were modeled using soil concentrations as only explanatory variable. For Cepaea snails, preliminary analyses (linear models) showed no difference of concentration between adult $C$. nemoralis and $C$. hortensis, whatever the metal. Metal concentrations in Cepaea sp individuals were thus modeled using age and soil concentrations as explanatory variables, without further considering the species. Third, GLM involving concentrations in snails tissues as a dependent variable and total metal concentrations in soils and soil properties as explanatory variables were performed. Preliminary monovariate analyses having shown that biotic variables (e.g. species when analyses were performed on the six snail species and age for Cepaea snails) were of primary importance in explaining metal concentrations in tissues, they were placed first in the models. Then, to assess the influence of soil properties conditionally to total soil concentrations, this last variable was placed in second in the models. These two variables in the model being fixed (biotic variables and total concentration), soil properties were added.

231 Precisely, the order of soil properties in the models was chosen according to preliminary 232 monovariate analyses linking concentrations in snails to soil properties. All soil variables were placed in the model in the decreasing order of their coefficient of determination $\left(R^{2}\right)$ 
234 obtained in monovariate analyses. The complete model was then analysed by ANOVA and 235 non-significant variables were excluded.

236 Post-hoc multiple comparisons were performed using Tukey's Honest Significant Difference 237 test $(p<0.05)$ to test significant differences of metal concentrations between species. Biota238 to-Soil Accumulation Factors (BSAFs) were calculated as the ratio of metal concentration in 239 the soft tissues on total metal concentration in the soil. The relationship between BSAF and 240 total soil concentration (conditionally to species) was assessed using a linear models.

241 When models had two variables, interactions between the variables were studied when 242 relevant. For all tests, significance was chosen at $p<0.05$. All statistical analyses were 243 performed using the software $\mathrm{R} 2.10 .1$ with pgirmess and ade4 packages 244 (RDevelopmentCoreTeam, 2010). 


\section{Results}

\subsection{Snail species, metal concentrations in soils and in snail and BSAF}

In the present paper, analyses were conducted on six out of the 19 species sampled. These six species were selected because they were relatively abundant and well spatially distributed over the study area. A total of 264 snail samples were found in 48 habitats within the 30 squares where they were sampled. The 264 snails include 20 copse snails (Arianta arbustorum), 47 white-lipped banded snails (Cepaea hortensis), 54 brown-lipped grove snails (Cepaea nemoralis) and 30 juvenile Cepaea sp snails, 19 garden snails (Cantareus aspersus, ex-Helix aspersa), 78 Draparnaudi's glass snails (Oxychilus draparnaudi) and 16 strawberry snails (Trichia striolata).

Soils from the study site were heavily polluted with metals (Table 1). Median total concentrations of $\mathrm{Cd}, \mathrm{Pb}$ and $\mathrm{Zn}$ were much higher than the background values of woody topsoils of the region which are $0.2,53.3$ and $53.4 \mathrm{\mu g} \mathrm{g}^{-1}$, respectively (Sterckeman et al., 2002a), except six topsoils that exhibited background concentrations. Soil properties varied greatly according to the different sampling sites (Table 1). Topsoil texture was mainly loamy to silty-loamy. All other soil properties exhibited large variations, up to one order of magnitude for organic matter content, showing a great variability of types of soils within the study area.

Metal concentrations in snail soft bodies were characterized by distinct patterns, which varied between species and as a function of the element considered (Table 1, Figure1). Median Cd concentrations in snails $\left(45.1 \mu \mathrm{g} \cdot \mathrm{g}^{-1}\right)$ were higher than those measured in soils $(p<0.001)$. Only Arianta arbustorum and juvenile Cepaea sp snails exhibited significant lower $\mathrm{Cd}$ concentration compared to other species (Figure 1). Inversely, $\mathrm{Pb}$ concentrations in snail tissues (median $\mathrm{Pb}$ concentration of $33.2 \mu \mathrm{g} \cdot \mathrm{g}^{-1}$ ) were lower than those measured in soils ( $\mathrm{p}$ $<0.001$ ). No significant intra-species differences were detected for $\mathrm{Pb}$ concentrations. Finally, $\mathrm{Zn}$ concentrations in snails were of the same order of magnitude than those found in soils $(\mathrm{p}=0.58)$. Higher $\mathrm{Pb}$ concentrations were measured for Oxychilus draparnaudi and Trichia striolata compared to other species (Figure 1).

Cd biota-to-soil accumulation factors (BSAF) were consistently higher than 1 for all species (Figure 2). The transfer of this metal was the lowest for $A$. arbustorum (median BSAF of 1.2) and juvenile Cepaea snails (median BSAF of 1.7), and the highest for T. striolata (median BSAF of 50.6) (data not shown). The four other species exhibited similar intermediate median BSAFs ranging from 3.5 to 7.4. For $\mathrm{Pb}$, median values of BSAF between species ranged from 0.031 to 0.13 and did not show inter-species differences, except for $T$. striolata, for which BSAFs reached 0.53 . The inter-species pattern was similar for $\mathrm{Zn}$, with all species 
exhibiting median BSAFs ranging from 0.49 to 1.23 , while it was 15.0 for $T$. striolata.

When considering all species together, the relationship of BSAF to exposure was significant and negative for all the metals considered (Figure 2, left). Comparing the carnivorous $O$. draparnaudi to the herbivorous Cepaea sp. (Figure 2, right), the decrease of BSAF values for $\mathrm{Cd}$ and $\mathrm{Pb}$ along the pollution gradient were significantly higher for Cepaea snails (slopes = 0.93 and -0.12 , respectively) than for 0 . draparnaudi (slopes $=-0.41$ and -0.05 , respectively). For Zn, BASF decreased similarly for Oxychilus (slope $=-0.35$ ) and Cepaea snails (slope = 0.37).

3.2 Influence of total or extractable concentrations, and of free metal ion activities in the soil solution on concentrations in snail tissues

294 Whatever the extraction, Cd concentrations in the 6 species of snails were poorly (at best $6.8 \%$ ) explained by total or extractable soil concentrations (Table 2). Three of the four steps of the sequential procedure even led to non significant relationships. No relationship (except for $\mathrm{Pb}_{\mathrm{b}}$ concentrations) was evidenced for $\mathrm{Pb}$. $\mathrm{Zn}$ concentrations in snail tissues were very poorly explained by soil concentrations. Whatever the metal, the influence of the species was always higher than that of soil concentrations (total or extractable) in explaining metal concentrations in snail soft tissues. Species and $\mathrm{Pb}_{\mathrm{b}}$ extracted concentrations accounted for $11 \%$ of the variation of $\mathrm{Pb}$ concentrations in snail tissues. Depending on the considered extraction, species and metal concentrations explained 18.3 to $21.7 \%$ of the variance for $\mathrm{Cd}$, and from 35.4 to $38.5 \%$ for $\mathrm{Zn}$. For both metals, however, some extractable concentrations were not significantly related to snail concentrations. The use of predicted free activities led to similar low correlations for each metal (Table 2). Considering all extractions together, the relationships between concentrations in $O$. draparnaudi snails and soil concentrations were much better than when all species were considered together and also better than for Cepaea snails (Table 2). Metal concentrations in O. draparnaudi tissues were never significantly correlated with free ion activities in the soil solution. Cadmium levels in $O$. draparnaudi increased significantly with total as well as extractable (all extractants) Cd concentrations in soils (Table 2). The various extractions explained from $5.5\left(\mathrm{Cd}_{d}\right)$ to $24.3 \%$ (acetic acid) of the variations of $\mathrm{Cd}$ concentrations in snails. Total as well as $\mathrm{Pb}_{d}$ concentrations were poorly related to $\mathrm{Pb}$ concentrations in snail tissues. Three other extractable concentrations (citric and acetic acids, and $\mathrm{Pb}_{\mathrm{b}}$ ) explained from 19.1 to $25.3 \%$ of the variations of $\mathrm{Pb}$ concentrations. $\mathrm{CaCl}_{2}$-extractable concentrations were the only non-significantly related concentrations for Zn. Zinc concentrations in snail tissues were best related $\left(25.2 \%\right.$ of variance explained) to $Z \mathrm{n}_{\mathrm{b}}$ concentrations. Total concentrations and the other extractants explained 13.7 and from 6.4 to $10.9 \%$ of the variations of $\mathrm{Zn}$ concentrations in snails, respectively. 
320 For Cepaea snails, two extractable $\mathrm{Cd}$ concentrations $\left(\mathrm{CaCl}_{2}\right.$ and $\left.\mathrm{Cd}_{\mathrm{b}}\right)$ and $\mathrm{pCd}{ }^{2+}$ were 321 significantly related to concentrations in soft tissues. For $\mathrm{Pb}$, only acetic acid extractable 322 concentrations and $\mathrm{pPb}^{2+}$ were significantly related to Cepaea tissue concentrations, the 323 relationship being negative for acetic acid. $\mathrm{CaCl}_{2}$-extractable and $\mathrm{Zn}_{\mathrm{r}}$ concentrations, and $324 \mathrm{pZn}^{2+}$ were significantly correlated with $\mathrm{Zn}$ concentrations in Cepaea tissues. Inversely to $O$. draparnaudi, predicted free ion activities in the soil pore water were significantly correlated to concentrations in Cepaea for all metals. Although Cd concentrations in Cepaea tissues were age-dependant, this was not the case for $\mathrm{Pb}$ and $\mathrm{Zn}$ (Table 2).

328 Generally speaking, for all metals, extractable concentrations were weakly correlated with snail concentrations when the six species were considered together. A specific analysis shows that few extractable concentrations were significantly although weakly related to Cepaea tissues. In $O$. draparnaudi, extractable concentrations better correlated with concentrations in snail tissues but the best extractant explained $24.3,25.3$ and $25.2 \%$ of the variance for $\mathrm{Cd}, \mathrm{Pb}$ and $\mathrm{Zn}$, respectively.

\subsection{Influence of soil properties on concentrations in snail tissues}

Models using soil properties (conditionally to species or age and total soil concentrations) were not more efficient (adjusted $\mathrm{R}^{2}$ of the models of $13.4,23.0$ and $41.6 \%$ for $\mathrm{Pb}, \mathrm{Cd}$ and $\mathrm{Zn}$, respectively) than extraction-based models to explain concentrations in soft tissues for the six species considered together (Table 3). The species still was the most important explaining variable. Considering the influence of total concentrations and soil properties separately (partial $R^{2}$ ), conditionally to species, total soil concentration was shown to be weakly related to concentrations in snails and was even non significant for $\mathrm{Pb}$. No clear trend concerning the influence of soil properties could be evidenced: one to three soil properties appeared to be significant depending on the metal of concern and, whatever the metal, explained no more than $4.6 \%$ of the variance of snail concentrations.

As observed for extraction-based models, $\mathrm{Pb}$ and $\mathrm{Zn}$ concentrations in snail soft tissues were better explained for $O$. draparnaudi than for Cepaea $s p$ (Table 3). For $\mathrm{Cd}$, adjusted $\mathrm{R}^{2}$ models were similar for both species with $30.0 \%$ for 0 . draparnaudi and $29.0 \%$ for Cepaea. Metal concentrations in $O$. draparnaudi were positively related with total metal concentrations in soils and negatively with organic matter contents. For $\mathrm{Cd}$, the influence of soil concentration was higher than that of organic matter whereas it was the contrary for $\mathrm{Pb}$ and $\mathrm{Zn}$.

353 For Cepaea, models involved more soil variables than for 0 . draparnaudi. As for extractionbased models, the age was an important variable to explain $\mathrm{Cd}$ concentrations in soft tissues. Its importance was lower for $\mathrm{Pb}$ and not significant for $\mathrm{Zn}$. Total metal concentrations 
357 concentrations for all metals. Organic matter was negatively correlated with snail 358 concentrations for $\mathrm{Cd}$, whereas it was positively correlated for $\mathrm{Pb}$ and $\mathrm{Zn}$.

359

360

361 


\section{Discussion}

363 4.1. BSAFs are influenced by both the species and the total soil concentration

364 For most species, median values of BSAF were around 5 for $\mathrm{Cd}$, which is in accordance with 365 Martin and Coughtrey who showed Cd bioaccumulation factors of 1.37-7.57 in various 366 species of snails (Martin and Coughtrey, 1982). Few inter-species differences were noted for $\mathrm{Pb}$, median BSAFs being lower than 0.5 for all species, indicating either an important excretion and/or a low assimilation of this metal. Except for Trichia striolata, median BSAFs for $\mathrm{Zn}$ values generally ranged from 0.5 to 1 . Our data showed a negative relationship between BSAFs and total soil concentrations for all investigated metals. The highest BCF values for all metals were at low exposure concentrations, while the lowest BCF values were at elevated metal exposure levels. These results are consistent with those of Spurgeon and Hopkin (Spurgeon and Hopkin, 1996) and Veltman et al (Veltman et al., 2008), who found inverse relationships between BASFs in animals from all trophic levels and metal concentrations in soils. Similarly, this trend has also been described in aquatic environments, with various aquatic species (McGeer et al., 2003). The fact that the BSAF decreases linearly with increasing soil concentration, almost with a slope of 1.0, indicates a significant degree of control over metal accumulation, probably regulation. A constant BSAF would in fact suggest the contrary, namely that metals level in the snails does increase with increasing soil concentrations. Consequently, our results suggest that the degree of control over metal accumulation was stronger for $\mathrm{Cd}$ than for $\mathrm{Zn}$. The relatively gentle slopes observed for $\mathrm{Pb}$ indicate that BSAF appear to be independent of the soil concentration. Moreover, slope differences observed for the carnivorous $O$. draparnaudi with the herbivorous Cepaea sp. suggest the influence of species for metal accumulation and regulation. The physiological basis for the inverse relationship of BSAF to metal exposure concentration arises from metal uptake and control mechanisms (McGeer et al., 2003). Lock and Janssen (2001) concluded that uptake rate constants for cadmium decrease with increasing metal concentration, based on experimental results on two terrestrial oligochaetes, Eisena fetida and Enchytraeus albidus. At low environmental $\mathrm{Zn}$ levels, snails are able to sequester and retain $\mathrm{Zn}$ in tissues for essential functions. When $\mathrm{Zn}$ exposure levels are elevated, snails are able to control bioaccumulation. Despite it is known that Cantareus aspersus snails are able to regulate $\mathrm{Pb}$ concentrations more closely than other metals (Beeby and Richmond, 2010), our results indicate no-regulation controls on $\mathrm{Pb}$ bioaccumulation. These authors suggest that $\mathrm{BSAF}$ are unreliable indicators of an evolved regulatory mechanism for $\mathrm{Pb}$. 
While selective and sequential extractions are frequently considered as a promising tool to measure environmental availability of trace metals in soils (Harmsen, 2007; ISO, 2008), relatively few data are available on relationships between extractable concentrations from field soils and concentrations in tissues of wild animals. Our data show that extractable concentrations from three selective and one sequential four-step extractions, as well as predicted free ions activities in the soil solution, explain up to $42 \%$ of the variations of the concentrations of $\mathrm{Cd}, \mathrm{Pb}$ and $\mathrm{Zn}$ in the tissues of snails sampled in the surroundings of $\mathrm{a}$ former $\mathrm{Pb}$-smelter and belonging to six species.

Among the data relating metal concentrations in wild animals with various soil extracts, earthworms are probably the most studied taxa. In three species of earthworms (Allolobophora chlorotica, Apporectodea caliginosa, and Lumbricus rubellus) from a moderately contaminated Dutch floodplain, $\mathrm{HNO}_{3}-, \mathrm{CaCl}_{2}$-extractable and pore water $\mathrm{Cd}, \mathrm{Cu}$, $\mathrm{Pb}$ and $\mathrm{Zn}$ concentrations in soils were non significantly correlated with concentrations in the worm tissues (Van Vliet and Van der Zee, 2005). Total soil concentrations were weakly $\left(\mathrm{R}^{2}<\right.$ 0.10 ) correlated with worms for $\mathrm{Cd}, \mathrm{Cu}$ and $\mathrm{Zn}$ but not for $\mathrm{Pb}$. Adding flooding, a frequent environmental stress in those habitats, as a new variable in the models allowed improving $\mathrm{R}^{2}$ to 0.67 for $\mathrm{Cd}, 0.10$ for $\mathrm{Cu}$ and 0.33 for $\mathrm{Zn}$. The relationship remained non significant for $\mathrm{Pb}$. Modeling each species separately, only total soil concentrations were significantly related to metal concentrations in worm tissues (not for all species or metals) with $\mathrm{R}^{2}$ ranging from 0.14 to 0.80 . As in the Dutch case on earthworms, our data showed that $\mathrm{Pb}$ concentrations in soils, whatever the extractant used, generally do not correlate with $\mathrm{Pb}$ concentrations in snails when all species are considered together. The influence of species is the most important variable explaining snail concentrations. In a study of another Dutch floodplain, $\mathrm{Cd}$ and $\mathrm{Cu}$ concentrations in $A$. caliginosa and $L$. rubellus have also been found to correlate best with total rather than to pore-water and $\mathrm{CaCl}_{2}$-extractable concentrations (Hobbelen et al., 2006).

In the present work, the use of free metal ion activities in the soil pore water to model metal concentrations in snails gave no better results than chemical extractions. This is in agreement with the results of a study aiming at using Helix aspersa snail as quantitative sentinels of total and predicted free $\mathrm{Pb}$ concentrations in soils (Beeby and Richmond, 2003). In this work where adult snails were sampled from 23 locations in England and Wales, correlations between free $\mathrm{Pb}$ activity calculated using the same equation (Sauvé et al., 1997) and $\mathrm{Pb}$ concentrations in snail tissues were low $\left(\mathrm{R}^{2}=0.16, \mathrm{p}<0.001\right)$. In a study on Eisenia fetida exposed to nine Cd-spiked soils, similar low relationships were found between free $\mathrm{Cd}$ activity and $\mathrm{Cd}$ accumulation in the worm tissues ( $\mathrm{Li}$ et al., 2009). However, the introduction of pore water $\mathrm{pH}$ as an explanatory variable increased $\mathrm{R}^{2}$ to 0.45 , indicating that $\mathrm{Cd}$ uptake 
434 by $E$. fetida may be moderated by the presence of other cations in the soil pore water, 435 especially $\mathrm{H}^{+}$ions.

436 In a synthesis of the researches undertaken on Dutch floodplains, van Gestel concluded that 437 bioavailability could not be predicted from available concentrations in pore water or $0.01 \mathrm{M}$ $438 \mathrm{CaCl}_{2}$ soil extracts (Van Gestel, 2008). Our results on several species of gastropod mollusks 439 reinforce the conclusion that extractable concentrations might not provide predictive models 440 accurate enough to be used in routine risk assessment.

441 Another key factor in understanding the transfer of metals from the environment to organisms 442 relies on food chain transfers. Indeed, in a study of metal transfers in a soil - plant (Urtica 443 dioica) - snail (Cepaea nemoralis), relationships between metal concentrations in plants and 444 snails were stronger than between soils and snails (Notten et al., 2005). The authors 445 interpreted this phenomenon as a major contribution of plant materials to the transfers of 446 metals to snails, compared to the contribution of the soil, which was, though, considered 447 significant. In a study aiming at evaluating $H$. aspersa snails as sentinels for mapping 448 pollution, however, correlations between soil and snail $\mathrm{Cd}$ concentrations were slightly higher 449 than correlations between Taraxacum leaves and snails (Beeby and Richmond, 2002), 450 suggesting a rather equal contribution of soil and plant in the accumulation of metals by the 451 snails. Moreover, the relative contribution of soil and plants in the accumulation of metals by 452 snails has been suggested to vary greatly depending on the metal considered (Scheifler et 453 al., 2006). Therefore, depending on the metal and on the actual diet of the different snail 454 species, relationships between metal concentrations in snail tissues and soil concentrations 455 are likely to drastically vary.

456 Snails have various diets depending on the considered species (Speiser, 2001) and 457 obviously do not only depend on the soil when considering their exposure and subsequent 458 contamination. Plants of all developmental stages (from seedlings to senescing plants), leaf 459 litter, wood, dead and even alive animals have been recorded as gastropod food (Speiser, 460 2001). Therefore, when the transfer of metals from the environment to the snail has to be 461 modelled, one should not only consider the soil on which snails are crawling and feeding but 462 also the rest of their diet. However, even in this case, one would obtain metal concentrations 463 in the soils and in various supposed food items, which would not allow modelling the 464 transfers without knowing the proportion of each item is actually ingested.

468 4.3. Modeling metal concentrations in snail tissues using soil total metal concentrations and 469 properties slightly increases predictions 
470 When data are handled with all species together, models associating total concentrations

471 and soil properties do not explain metal concentrations in snail tissues better than extraction-

472 based ones, the influence of the species remaining the most important variable. Looking at

473 species separately, however, the models using soil properties are generally slightly better

474 than extraction-based. To our knowledge, only few studies investigated the role of soil 475 properties in explaining metal accumulation in wild snail tissues. In the present study, soil pH 476 was found to be inversely related to the accumulation of metals in snails. Soil $\mathrm{pH}$ affects the 477 partitioning of metals in the different soil compartments and, therefore, the metal 478 concentration available for exposure from soil solution. Several studies performed on in situ 479 contaminated soils with different species of worms found that total metal concentrations in 480 soils was a poor predictor of earthworm metal accumulation due to a number of modifying 481 factors such as $\mathrm{pH}$, organic matter content, and clay particle content (Nahmani et al., 2007). 482 In the present study, metal concentrations in $O$. draparnaudi snails increased with total 483 concentrations and decreased with organic matter values, as also observed on Lumbricus 484 rubellus (Corp and Morgan, 1991). This suggests that metal adsorption on organic matter occurred, reducing the bioavailability of metals at high organic matter contents. Clay content has also been found to negatively influence metal availability for animals at high contents (Janssen et al., 1997; Owojori et al., 2010). In our study, clay content was positively correlated with $\mathrm{Pb}$ concentrations in the six species considered together and in Cepaea snails, but not in Oxychilus individuals. Our results also showed a negative relationship between tissues $\mathrm{Cd}$ and $\mathrm{Pb}$ concentrations in the six species and in Cepaea snails and silt content, but this was not observed in Oxychilus snails. Taken together, our results do not show a straightforward influence of soil properties, whose influence was species- and metalspecific.

\section{Conclusion}

497 In this study, metal concentrations in snails were poorly explained by total and extractable 498 soil concentrations, whatever the chemical extractant, and by predicted free ion activities in 499 the soil solution. When total metal concentrations and soil characteristics were used as explanatory variables, the explanation of the variations of metal concentrations in snail tissues slightly increased, particularly when data were handled species-specifically, but remained lower than $42 \%$. Biotic parameters like species when a multi-species dataset is studied, or age when it can be determined (i.e. for certain species for which a method exists), were of primary importance in explaining snail tissue concentrations. Taken together, those results suggest that correlations between snail tissues and external (total, or extractable 
507 purposes. Data coming from laboratory or microcosm studies, particularly those using freshly

508 spiked soils, sometimes show better or even good relationships between invertebrate tissue

509 and external concentrations, and this has lead to consider chemical extractions as a 510 promising tool to predict metal bioavailability. The few field data (mainly on worms and, in the 511 present work, on snails) reinforce the well known feeling that extrapolation from laboratory to 512 field conditions is not straightforward and that both approaches should be combined to 513 understand and to predict bioavailability. Moreover, important insights have to be gained in 514 food web approaches allowing determining food web structure and composition, and hence, 515 a better understanding of the transfer (and subsequent effects) of contaminants in 516 ecosystems.

\section{Acknowledgements}

519 Francis Douay and his colleagues from the Laboratoire Sols et Environnement are gratefully 520 acknowledged for having performed soil samples and analyses. We warmly thank Cécile 521 Grand from the Agence De l'Environnement et de la Maîtrise de l'Energie (ADEME) for many 522 fruitful scientific discussions. The STARTT programme is financially supported by the Agence 523 Nationale de la Recherche (ANR, contract $n^{\circ}$ ANR-05-ECCO-004) and the ADEME (contract $524 n^{\circ}$ 0572C0058). Patrick Giraudoux, Francis Raoul and Dominique Rieffel are acknowledged 525 for their help in field work. Brice Mourier is supported by a grant from the Centre National de 526 la Recherche Scientifique (CNRS). 
528 Table 1. Descriptive statistics of total concentrations of $\mathrm{Cd}, \mathrm{Pb}$ and $\mathrm{Zn}$ in the $25 \mathrm{~cm}$ soil

529 layer $(n=48)$ and in snail soft bodies $(n=264)$, and physico-chemical parameters of soils,

530 from the former "Metaleurop-Nord" smelter (Noyelles-Godault, France). Different letters

531 represent significant differences of metal concentrations between soils and snails according

532 to linear models.

\begin{tabular}{|c|c|c|c|c|c|c|c|c|c|c|c|}
\hline & $\mathrm{Cd}_{\text {soil }}$ & $\mathrm{Pb}_{\text {soil }}$ & $\mathrm{Zn}_{\text {soil }}$ & $\mathrm{Cd}_{\text {snail }}$ & $\mathrm{Pb}_{\text {snail }}$ & $\mathrm{Zn}_{\text {snail }}$ & OM & Clay & Silt & CEC & $\mathrm{pH}$ \\
\hline & \multicolumn{6}{|c|}{$\mu g \cdot g^{-1}$} & \multicolumn{3}{|c|}{ g. $\mathrm{kg}^{-1}$} & \multicolumn{2}{|l|}{$\mathrm{cmol}^{+} \cdot \mathrm{kg}^{-1}$} \\
\hline Minimum & 0.7 & 74.7 & 87.5 & 4.3 & 4.2 & 164 & 24 & 29 & 90 & 7.4 & 4.0 \\
\hline $1^{\text {st }}$ quartile & 5.3 & 266 & 405 & 24.6 & 16.9 & 381 & 55 & 146 & 328 & 14.0 & 6.2 \\
\hline Median & 10.7 & 402 & 672 & 45.1 & 33.2 & 606 & 78 & 197 & 414 & 19.2 & 7.8 \\
\hline Mean & $11.9^{\mathrm{a}}$ & $733^{a}$ & $882^{a}$ & $52.9^{b}$ & $63.0^{b}$ & $836^{a}$ & 107 & 212 & 431 & 18.3 & 7.1 \\
\hline $3^{\text {rd }}$ quartile & 14.1 & 1144 & 1304 & 66.7 & 76.2 & 1029 & 150 & 243 & 520 & 21.0 & 7.9 \\
\hline Maximum & 104 & 2360 & 3790 & 258 & 825 & 6619 & 243 & 391 & 719 & 29.2 & 8.3 \\
\hline
\end{tabular}

533 
535 Table 2. Partial $R^{2}$ of explanatory variables (when significant) and adjusted- $R^{2}$ of the models

536 (in brackets, when significant) linking snail metal concentrations to soil concentrations (total

537 or extractable) and free metal ion activities in the soil solution $\left(\mathrm{pMetal}^{2+}\right)$. Best $\mathrm{R}^{2}$ are

538 indicated in bold. Negative relationships between metal concentrations in snail tissues and

539 explanatory variables are indicated in between bracket (-). Partial $R^{2}$ of biotic variables

540 (species or age) can be deduced by subtracting values of partial $\mathrm{R}^{2}$ of soil concentrations

541 from the $\mathrm{R}^{2}$ of the model.

\begin{tabular}{|c|c|c|c|c|c|c|c|c|c|}
\hline TM & {$[\mathrm{TM}]_{\text {total }}$} & {$[\mathrm{TM}]_{\mathrm{CaCl} 2}$} & {$[\mathrm{TM}]_{\text {citric acid }}$} & {$[\mathrm{TM}]_{\text {acetic acid }}$} & {$[\mathrm{TM}]_{\mathrm{a}}$} & {$[\mathrm{TM}]_{\mathrm{b}}$} & {$[\mathrm{TM}]_{\mathrm{d}}$} & {$[\mathrm{TM}]_{\mathrm{r}}$} & $\mathrm{pTM}^{2+}$ \\
\hline \multicolumn{10}{|c|}{6 snail species $\left(n=264\right.$, model: $\log _{10}[\mathrm{TM}+1]_{\text {snail }} \sim$ species $\left.+\log _{10}[\text { total or extractable } \mathrm{TM}+1]_{\text {soil }}\right)$} \\
\hline $\mathrm{Cd}$ & $\begin{array}{r}3.2 \\
(20.2)\end{array}$ & $\begin{array}{r}5.7 \\
(18.3)\end{array}$ & $\begin{array}{r}4.6 \\
(20.5)\end{array}$ & $\begin{array}{r}6.0 \\
(21.7)\end{array}$ & $\begin{array}{r}\mathrm{ns}^{\mathrm{a}} \\
(17.0)\end{array}$ & $\begin{array}{r}6.8 \\
(20.2)\end{array}$ & $\begin{array}{r}\text { ns } \\
(14.8)\end{array}$ & $\begin{array}{r}\mathrm{ns} \\
(16.9)\end{array}$ & $\begin{array}{l}2.3(-) \\
(15.5)\end{array}$ \\
\hline $\mathrm{Pb}$ & $\begin{array}{r}\mathrm{ns} \\
(6.4)\end{array}$ & $\begin{array}{r}\mathrm{Ns} \\
(5.6)\end{array}$ & $\begin{array}{r}\mathrm{ns} \\
(8.4)\end{array}$ & $\begin{array}{r}n s \\
(14.1)\end{array}$ & $\begin{array}{r}\mathrm{ns} \\
(3.7)\end{array}$ & $\begin{array}{l}2.4(-) \\
(11.0)\end{array}$ & $\begin{array}{r}\mathrm{ns} \\
(5.8)\end{array}$ & $\begin{array}{r}\text { ns } \\
(5.9)\end{array}$ & $\begin{array}{r}3.5(-) \\
(8.6)\end{array}$ \\
\hline $\mathrm{Zn}$ & $\begin{array}{r}2.9 \\
(39.5)\end{array}$ & $\begin{array}{r}\mathrm{Ns} \\
(36.1)\end{array}$ & $\begin{array}{l}2.0(-) \\
(38.5)\end{array}$ & $\begin{array}{r}\mathrm{ns} \\
(37.3)\end{array}$ & $\begin{array}{r}1.1 \\
(36.5)\end{array}$ & $\begin{array}{r}3.6 \\
(42.1)\end{array}$ & $\begin{array}{r}1.7 \\
(37.4)\end{array}$ & $\begin{array}{r}3.1 \\
(38.7)\end{array}$ & $\begin{array}{l}2.2(-) \\
(37.8)\end{array}$ \\
\hline
\end{tabular}

Oxychilus draparnaudi $\left(n=78\right.$, model: $\left.\log _{10}[\mathrm{TM}+1]_{\text {snail }} \sim \log _{10}[\text { total or extractable } \mathrm{TM}+1]_{\text {soil }}\right)$

$\begin{array}{cccccccccc}\mathrm{Cd} & 21.9 & 8.6 & 23.1 & \mathbf{2 4 . 3} & 11.5 & 11.8 & 5.5 & 7.3 & \mathrm{~ns} \\ \mathrm{~Pb} & 7.0 & \mathrm{Ns} & 19.1 & 23.0 & \mathrm{~ns} & \mathbf{2 5 . 3} & 7.4 & \mathrm{~ns} & \mathrm{~ns} \\ \mathrm{Zn} & 13.7 & \mathrm{Ns} & 10.9 & 6.4 & 4.4 & \mathbf{2 5 . 2} & 7.2 & 7.6 & \mathrm{~ns}\end{array}$

Cepaea $s p\left(n=131\right.$, model: $\log _{10}[\mathrm{TM}+1]_{\text {snail }} \sim$ age $\left.+\log _{10}[\text { total or extractable } \mathrm{TM}+1]_{\text {soil }}\right)$

\begin{tabular}{|c|c|c|c|c|c|c|c|}
\hline $\begin{array}{r}\text { ns } \\
(16.5)\end{array}$ & $\begin{array}{r}\mathbf{5 . 1} \\
(21.7)\end{array}$ & $\begin{array}{r}\mathrm{ns} \\
(16.8)\end{array}$ & $\begin{array}{r}n s \\
(18.3)\end{array}$ & $\begin{array}{r}\mathrm{ns} \\
(17.8)\end{array}$ & $\begin{array}{r}4.9 \\
(21.5)\end{array}$ & $\begin{array}{r}\text { ns } \\
(20.1)\end{array}$ & $\begin{array}{r}n s \\
(20.6)\end{array}$ \\
\hline ns & Ns & ns & $\begin{array}{r}8.1(-) \\
(9.6)\end{array}$ & $\mathrm{ns}$ & ns & ns & ns \\
\hline ns & $\begin{array}{r}3.2 \\
(3.2)\end{array}$ & ns & ns & $\mathrm{ns}$ & ns & ns & $\begin{array}{r}3.9 \\
(3.9)\end{array}$ \\
\hline
\end{tabular}


544 Table 3. Partial $R^{2}$ of each variable, models and their adjusted- $R^{2}$ (Adj- $R^{2}$ ) for relationships

545 linking snail metal concentrations to biotic variables (species and age), external total metal

546 concentrations and soil properties in 6 snail species, in Oxychilus draparnaudi and in Cepaea

$547 s p$. The negative or positive relationship between metal concentration in snail tissues and

548 each quantitative explanatory variable is indicated by a sign minus or plus in bracket.

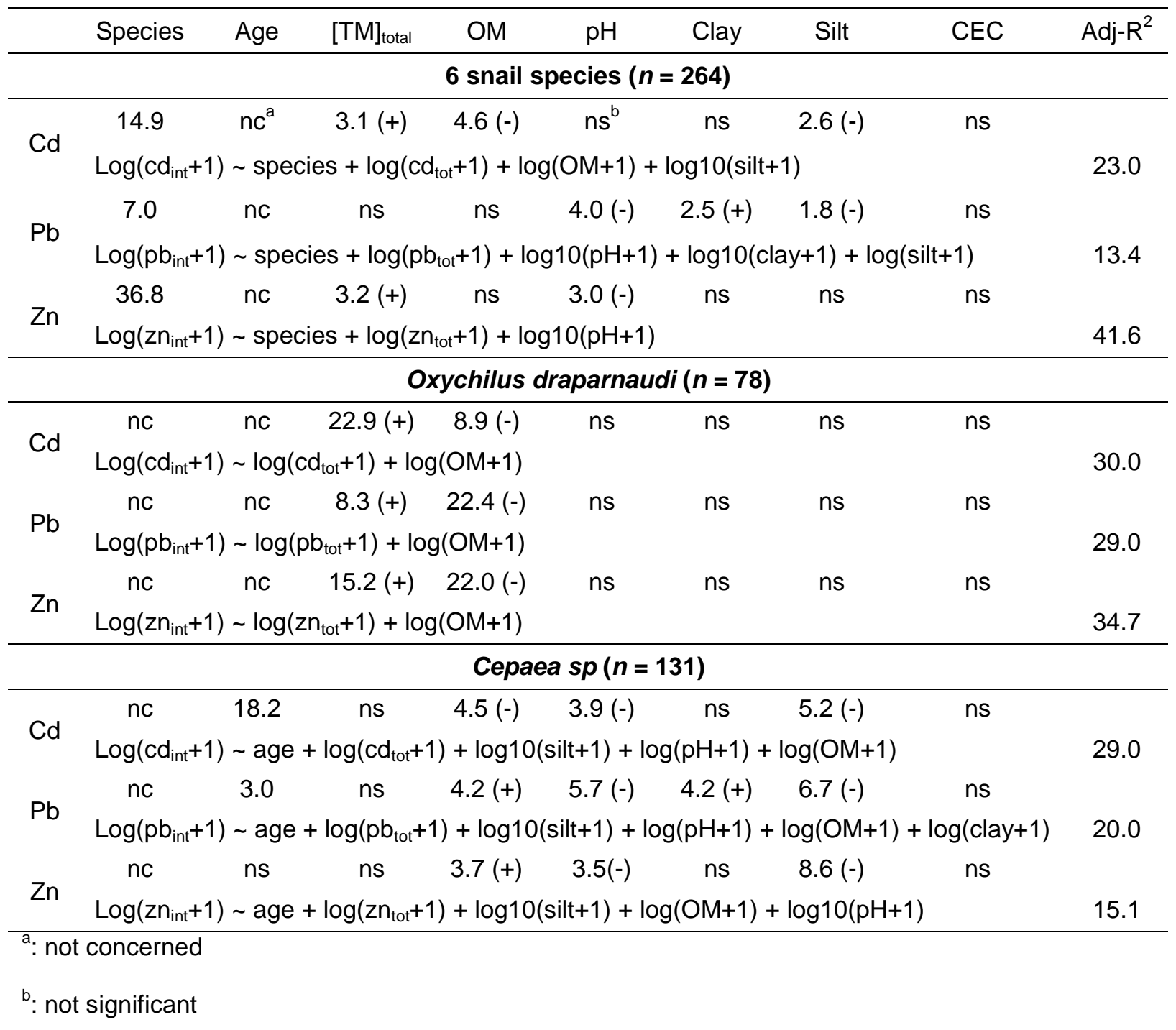




\section{Figure captions}

554 Figure 1. $\mathrm{Cd}, \mathrm{Pb}$ and $\mathrm{Zn}$ concentrations $\left(\mu \mathrm{g} \cdot \mathrm{g}^{-1} \mathrm{dw}\right)$ measured in soft tissues of each snail 555 species sampled in the area of the former "Metaleurop-Nord" smelter (Noyelles-Godault, 556 France). AA: Arianta arbustorum, CH: Cepaea hortensis (adults), CJ: juvenile of Cepaea sp., 557 CN: Cepaea nemoralis (adults), HA: Helix aspersa (syn. Cantareus aspersus), OD: 558 Oxychilus draparnaudi, TS: Trichia striolata.

559

560 Figure 2. $\mathrm{Cd}, \mathrm{Pb}$ and $\mathrm{Zn}$ biota-to-soil accumulation factors (BSAF) for snails as a function of 561 soil total metal concentrations $\left(\mu \mathrm{g} \cdot \mathrm{g}^{-1} \mathrm{dw}\right)$ for 6 snail species (left) and for Oxychilus 562 draparnaudi (OD) and Cepaea sp. (Csp) individuals (right) sampled in the area of the former 563 "Metaleurop-Nord" smelter (Noyelles-Godault, France). Lines represent model predictions 564 with associated coefficients (slope and intercept). For the purpose of readability, metal 565 concentration values are given in $\mu \mathrm{g} \cdot \mathrm{g}^{-1} \mathrm{dw}$ in both $\mathrm{x}$ - and $\mathrm{y}$-axis of the figure. The equations 566 exhibit log-transformed values. 
$568 \quad$ Figure 1.
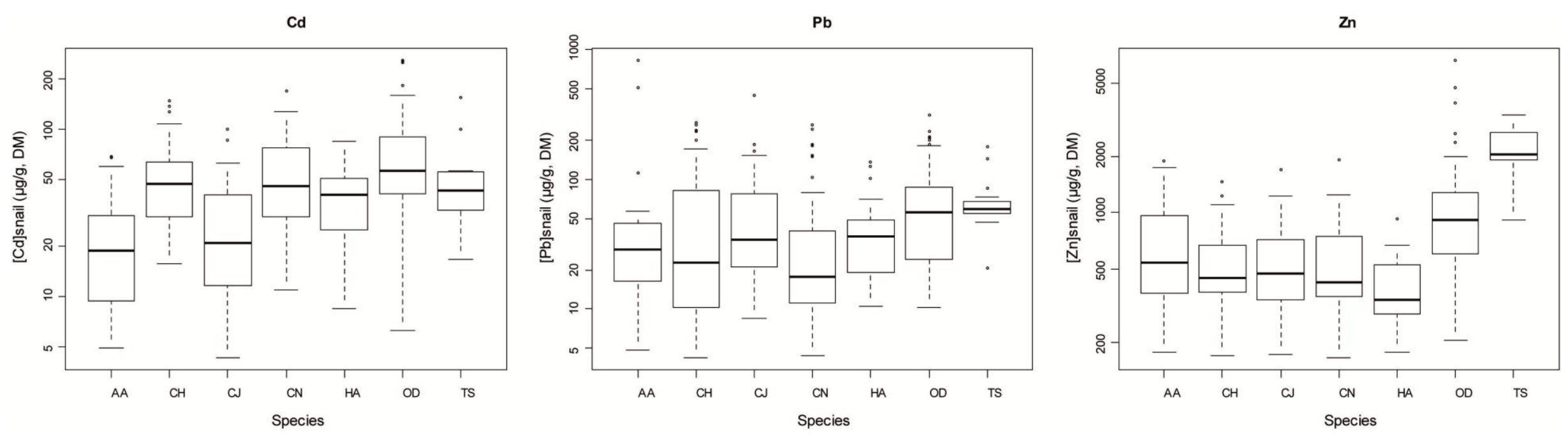


\section{$572 \quad$ Figure 2.}

573
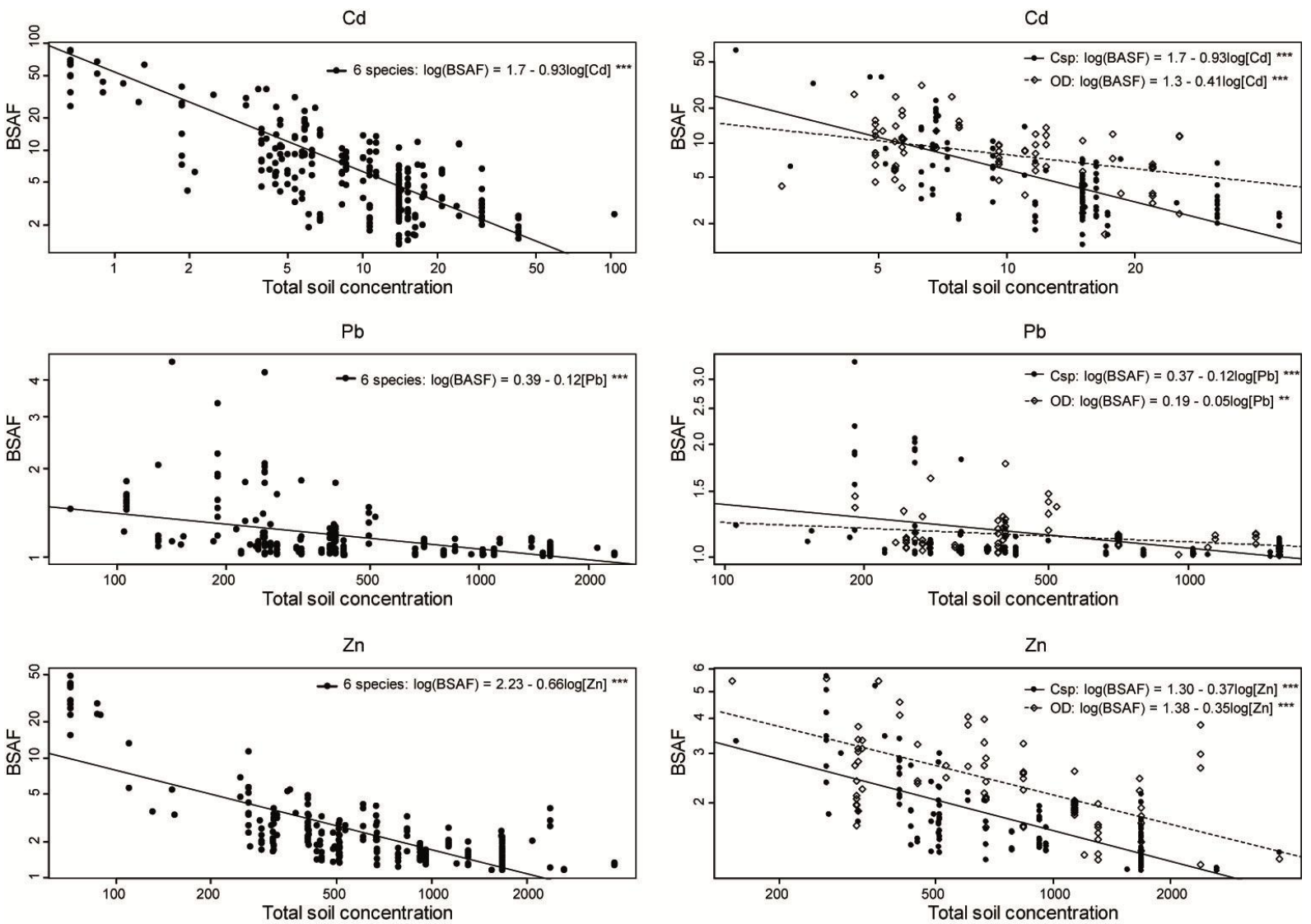


\section{References}

Ahumada, I., Escudero, P., Ascar, L., Mendoza, J., Richter, P., 2004. Extractability of arsenic, copper, and lead in soils of a mining and agricultural zone in central Chile. Commun Soil Sci Plan. 35, 1615-1634.

Beeby, A., Richmond, L., 2002. Evaluating Helix aspersa as a sentinel for mapping metal pollution. Ecol Indic. 1, 261-270.

Beeby, A., Richmond, L., 2003. Do the soft tissues of Helix aspersa serve as a quantitative sentinel of predicted free lead concentrations in soils? Appl Soil Ecol. 22, 159-165.

Beeby, A. \& Richmond, L. 2010. Magnesium and the regulation of lead in three populations of the garden snail Cantareus aspersus. Environmental Pollution. 158(6): 2288-2293.

Berger, B., Dallinger, R., 1993. Terrestrial snails as quantitative indicators of environmental metal pollution. Environ Monit Assess. 25, 65-84.

Corp, N., Morgan, A.J., 1991. Accumulation of heavy metals from polluted soils by the earthworm, Lumbricus rubellus: can laboratory exposure of 'control' worms reduce biomonitoring problems? Environ Pollut. 74, 39-52.

Douay, F., Pruvot, C., Roussel, H., Ciesielski, H., Fourrier, H., Proix, N., Waterlot, C., 2008. Contamination of urban soils in an area of Northern France polluted by dust emissions of two smelters. Water Air Soil Poll. 188, 247-260.

Douay, F., Pruvot, C., Waterlot, C., Fritsch, C., Fourrier, H., Loriette, A., Bidar, G., Grand, C., de Vaufleury, A., Scheifler, R., 2009. Contamination of woody habitat soils around a former lead smelter in the North of France. Sci Total Environ. 407, 5564-5577.

Fritsch, C., 2010. Utilisation intégrée de bioindicateurs pour la surveillance des sols et des écosystèmes terrestres. UMR 6249 UFC/CNRS Chrono-Environnement UsC INRA. PhD Thesis, Université de Franche-Comté, Besançon, France.

Fritsch, C., Giraudoux, P., Coeurdassier, M., Douay, F., Raoul, F., Pruvot, C., Waterlot, C., de Vaufleury, A., Scheifler, R., 2010. Spatial distribution of metals in smelter-impacted soils of woody habitats: influence of landscape and soil properties, and risk for wildlife. Chemosphere. 81, 141155.

Grafen, A., Hails, R., 2002. Modern statistics for the life sciences. Oxford University Press, Oxford, UK.

Harmsen, J., 2007. Measuring bioavailability: from a scientific approach to standard methods. J Environ Qual. 36, 1420-1428.

Hass, A., Fine, P., 2010. Sequential selective extraction procedures for the study of heavy metals in soils, sediments, and waste materials: a critical review. Crit Rev Env Sci Tec. 40, 365-399.

Hobbelen, P.H.F., Koolhaas, J.E., van Gestel, C.A.M., 2006. Bioaccumulation of heavy metals in the earthworms Lumbricus rubellus and Aporrectodea caliginosa in relation to total and available metal concentrations in field soils. Environ Pollut. 144, 639-646.

ISO, 2008. Soil quality - Requirements and guidance for the selection and application of methods for the assessment of bioavailability of contaminants in soil and soil materials. ISO 17402:2008. International Organization for Standardization, Geneva, Switzerland.

Janssen, R.P.T., Posthuma, L., Baerselman, R., Den Hollander, H.A., Van Veen, R.P.M., Peijnenburg, W.J.G.M., 1997. Equilibrium partitioning of heavy metals in Dutch field soils. II. Prediction of metal accumulation in earthworms. Environ Toxicol Chem. 16, 2479-2488.

Kerney, M.P., Cameron, R.A.D., 2006. Guide des escargots et limaces d'Europe. Delachaux et Niestlé, Paris, France.

Li, L.Z., Zhou, D.M., Wang, P., Allen, H.E., Sauve, S., 2009. Predicting Cd partitioning in spiked soils and bioaccumulation in the earthworm Eisenia fetida. Appl Soil Ecol. 42, 118-123.

Lock K, Janssen CR. Zinc and cadmium body burdens in terrestrial oligochaetes: use and significance in environmental risk assessment. Environ Toxicol Chem 2001;20:2067-72.

Lukkari, T., Taavitsainen, M., Väisänen, A., Haimi, J., 2004. Effects of heavy metals on earthworms along contamination gradients in organic rich soils. Ecotox Environ Safe. 59, 340-348.

McGeer, J. C., Brix, K. V., Skeaff, J. M., DeForest, D. K., Brigham, S. I., Adams, W. J. \& Green, A. 2003. Inverse relationship between bioconcentration factor and exposure concentration for metals: Implications for hazard assessment of metals in the aquatic environment. Environmental Toxicology and Chemistry. 22(5): 1017-1037.

Martin, M.H., Coughtrey, P.J., 1982. Biological monitoring of heavy metal pollution: land and air. in: Mellanby, K. (Ed.). Applied Science Publishers, London, UK, pp. 253-271.

Meers, E., Du Laing, G., Unamuno, V., Ruttens, A., Vangronsveld, J., Tack, F.M.G., Verloo, M.G., 2007. Comparison of cadmium extractability from soils by commonly used single extraction protocols. Geoderma. 141, 247-259. 
Morgan, J.E., Morgan, A.J., 1999. The accumulation of metals ( $\mathrm{Cd}, \mathrm{Cu}, \mathrm{Pb}, \mathrm{Zn}$ and $\mathrm{Ca}$ ) by two ecologically contrasting earthworm species (Lumbricus rubellus and Aporrectodea caliginosa): implications for ecotoxicological testing. Appl Soil Ecol. 13, 9-20.

Nahmani, J., Hodson, M.E., Black, S., 2007. A review of studies performed to assess metal uptake by earthworms. Environ Pollut. 145, 402-424.

Notten, M.J.M., Oosthoek, A.J.P., Rozema, J., Aerts, R., 2005. Heavy metal concentrations in a soilplant-snail food chain along a terrestrial soil pollution gradient. Environ Pollut. 138, 178-190.

Owojori, O.J., Reinecke, A.J., Rozanov, A.B., 2010. Influence of clay content on bioavailability of copper in the earthworm Eisenia fetida. Ecotox Environ Safe. 73, 407-414.

Peijnenburg, W.J.G.M., Jager, T., 2003. Monitoring approaches to assess bioaccessibility and bioavailability of metals: matrix issues. Ecotox Environ Safe. 56, 63-77.

R Development Core Team, 2010. R: a language and environment for statistical computing. R Foundation for Statistical Computing, Vienna, Austria.

Sauvé, S., McBride, M.B., Hendershot, W.H., 1997. Speciation of lead in contaminated soils. Environ Pollut. 98, 149-155.

Sauvé, S., Norvell, W.A., McBride, M., Hendershort, W., 2000. Speciation and complexation of cadmium in extracted soil solutions. Environ Sci Technol. 34, 291-296.

Scheifler, R., De Vaufleury, A., Coeurdassier, M., Crini, N., Badot, P.M., 2006. Transfer of Cd, Cu, Ni, $\mathrm{Pb}$, and $\mathrm{Zn}$ in a soil-plant-invertebrate food chain: A microcosm study. Environ Toxicol Chem. 25, 815-822.

Smolders, E., Oorts, K., van Sprang, P., Schoeters, I., Janssen, C.R., McGrath, S.P., McLaughlin, M.J., 2009. Toxicity of trace metals in soil as affected by soil type and aging after contamination: using calibrated bioavailability models to set ecological soil standards. Environ Toxicol Chem. 28, 1633-1642.

Speiser, B., 2001. Food and Feeding Behaviour. in: Barker, G.M. (Ed.). The Biology of Terrestrial Molluscs. CABI Publishing, Oxon, UK, pp. 259-288.

Spurgeon, D.J., Hopkin, S.P., 1996. Risk assessment of the threat of secondary poisoning by metals to predators of earthworms in the vicinity of a primary smelting works. Sci Tot Environ. 187, 167183.

Stephan, C.H., Courchesne, F., Hendershort, W.H., McGrath, S.P., Chaudri, A.M., Sappin-Didier, V., Sauvé, S., 2008. Speciation of zinc in contaminated soils. Environ Pollut. 155, 208-216.

Sterckeman, T., Douay, F., Fourrier, H., Proix, N., 2002a. Référentiel pédo-géochimique du Nord-Pas de Calais. Conseil Régional du Nord-Pas de Calais, Ministère de l'Aménagement du Territoire et de l'Environnement, Lille, France, p. 130.

Sterckeman, T., Douay, F., Proix, N., Fourrier, H., Perdrix, E., 2002b. Assessment of the contamination of cultivated soils by eighteen trace elements around smelters in the North of France. Water Air Soil Pollut. 135, 173-194.

Suter II, G.W., 1993. Exposure. in: Suter II, G.W. (Ed.). Ecological Risk Assessment. Lewis Publishers, Boca Raton, FL, pp. 153-172.

Van Gestel, C.A.M., 2008. Physico-chemical and biological parameters determine metal bioavailability in soils. Sci Tot Environ. 406, 385-395.

Van Vliet, P.C.J., Van der Zee, S.E.A.T.M., 2005. Heavy metal concentrations in soil and earthworms in a floodplain grassland. Environ Pollut. 138, 505-516.

Veltman, K., Huijbregts, M.A.J., Hendriks, A.J., 2008. Cadmium bioaccumulation factors for terrestrial species: Application of the mechanistic bioaccumulation model OMEGA to explain field data. Sci Tot Environ. 406, 413-418.

Williamson, P., 1979. Age determination of juvenile and adult Cepaea. J Mollus Stud. 45, 52-60. 